\title{
E-Service Quality, E-Loyalty, and E-Satisfaction Muslim Travellers
}

\author{
Malikhatul Mar'ati ${ }^{1}$, Muhammad Ali Faisal $^{2}$, Ikhsan Dwi Anggoro ${ }^{3}$, and Saiful Anwar ${ }^{*}$ \\ ${ }^{1}$ Faculty Islamic Economics and Business, IAIN Salatiga, Indonesia \\ ${ }^{2}$ Faculty Economics and Business, Gadjah Mada University, Indonesia \\ ${ }^{3}$ Faculty Economics and Business, Sebelas Maret University, Indonesia
}

\begin{abstract}
This study aims to determine the effect of e-service quality on eloyalty with e-satisfaction as an intervening variable for muslim travellers. The population are Traveloka users in Java. Purposive random sampling are used. The sample was obtained from 170 respondents by online collecting data questionnaire. SPSS 21.0 program are used to data analyze. The analytical tool were Multiple Regression and Path Analysis. The results showed that: e-service quality aspects of reliability, tangible, and empathy had a positive and significant effect on e-satisfaction. E- satisfaction and EService have a positive and significant impact on e- loyalty. E-satisfaction can mediate the impact of reliability, tangible, and empathy on e-loyalty, while responsiveness and assurance do not mediate the effect of esatisfaction on e-loyalty The results of this study can theoretically strengthen the existing theory that e-satisfaction can mediate the effect of reliability, tangible and empathy on e-loyalty, while responsiveness and assurance do not mediate the impact of e-satisfaction on e-loyalty. The practical implications in this study are used as input for platform provider to improve the quality of services provided by platform provider to muslim travelers.
\end{abstract}

Keywords: E-Service Quality; E-Loyalty; E-Satisfaction

\section{Introduction}

Along with the rapid development of technology and information today, the human need for the use of technology, especially the internet in daily life, also increases, because almost all human needs can be met through their devices via an internet connection. Data from the Indonesian Internet Service Providers Association shows that in 2020 there were 171.17 million internet users in Indonesia, an increase of $10.12 \%$ from the year before 2018.

The industrial sector is one of the business sectors that has experienced significant changes with the development of the internet, especially the tourism industry. Nowadays tourists no longer have to come and book their lodging and travel tickets manually because it is long and full of uncertainty. This is used by entrepreneurs to facilitate tourists to be able to book travel tickets as well as lodging through an application that they provide as long as

* Corresponding author: saifulanwarmieta@iainsalatiga.ac.id 


\section{$A I C \overline{I E B} \quad$ Annual International Conference \\ on Islamic Economics and Business, 2021}

tourists have internet access. Similar Web data in 2018 shows that Traveloka is the largest digital-based travel and lodging booking application in Indonesia, which controls $70.37 \%$ of the market. According to Jonathan, good E-Service Quality will create loyal consumers, in line with this Hamdallah and Prasmara also explained that E-Loyality comes from customer satisfaction from the good services provided.

Based on this, Traveloka always innovates to satisfy their consumers even though it experienced a $12 \%$ decline in turnover in 2020 due to the covid-19 pandemic. The majority of Traveloka consumers are local tourists and the majority of Indonesia's population is Muslim, with 225 million people $(86.88 \%)$ according to katadata.id. Therefore, the satisfaction of Muslim tourists in Indonesia is the main target of Traveloka's business process by always innovating for consumer satisfaction.

Research that has previously been reviewed by Tobagus (2018), Hidayah \& Utami (2017), Haria \& Mulyandi (2019) and Fitriani (2018) proves that e-service quality has a significant positive effect on e-satisfaction and is contrary to Gotama \& Indarwati (2019) dan Suprapti \& Suparmi (2020) which shows the results that e-service quality has no effect on esatisfaction. Then the previous research that has been reviewed by Irwansyah \& Mappadeceng (2018), Ashoer et al. (2019), Prasmara et al. (2020), Sativa (2016), Hendika et al. (2011), Nasution et al. (2019), Magdalena \& Jaolis (2018), Riza \& Sutopo (2017), and Budiman et al. (2020) proves that e-service quality has a significant positive effect on eloyalty and is contrary to Syafiq \& Haryono (2010), Komara (2013), Wulandari (2017), Pudjarti et al. (2019) and Melinda (2017) which shows the results that e-service quality has no effect on e-loyalty. Then the previous research that has been reviewed by Magdalena \& Jaolis (2018), Riza \& Sutopo (2017), Suprapti \& Suparmi (2020), Budiman et al. (2020), Ashoer et al. (2019), and Asih \& Pratomo (2018) proves that e-satisfaction has a significant positive effect on e-loyalty and is contrary to Boohene \& Agyapong (2011) shows the results that e- satisfaction has no effect on e-loyalty.

\section{Literature Review}

\subsection{Theory of Planned Behavior}

Mahyarni (2013) revealed that the Theory of reasoned action (TRA) was updated and developed with the theory of planned behavior (TPB) in order to predict a person's behavior when a person is not able to control himself. The difference between TRA and TPB is the direction of behavior, namely perceived behavioral control (PBC), which means that one's view of behavior affects one's motivation.

\subsection{E-Service Quality}

E-Service Quality is the response of Muslim tourists regarding disputes between desired and received services (Wulandari, 2017). There are five indicators that can be used to determine service quality, namely reliability, responsiveness, assurance, empathy and tangible (Harianto, 2013).

\subsection{E-Loyalty}

E-Loyalty is a customer's attitude and commitment to the company to generate an intention to repurchase the company at a later time and not at other companies. (Rahayu, 2020). 


\section{$A I C \overline{I E B} \quad$ Annual International Conference \\ on Islamic Economics and Business, 2021}

\subsection{E-Satisfaction}

E-Satisfaction, namely when the product or service exceeds the expectations of Muslim tourists, the level of satisfaction of Muslim tourists after being compared between the shopping experience and the expectations that will be felt after purchase. Udo et al. (2010) revealed that there are three indicators of e-satisfaction, namely positive things, pleasant service and satisfying service.

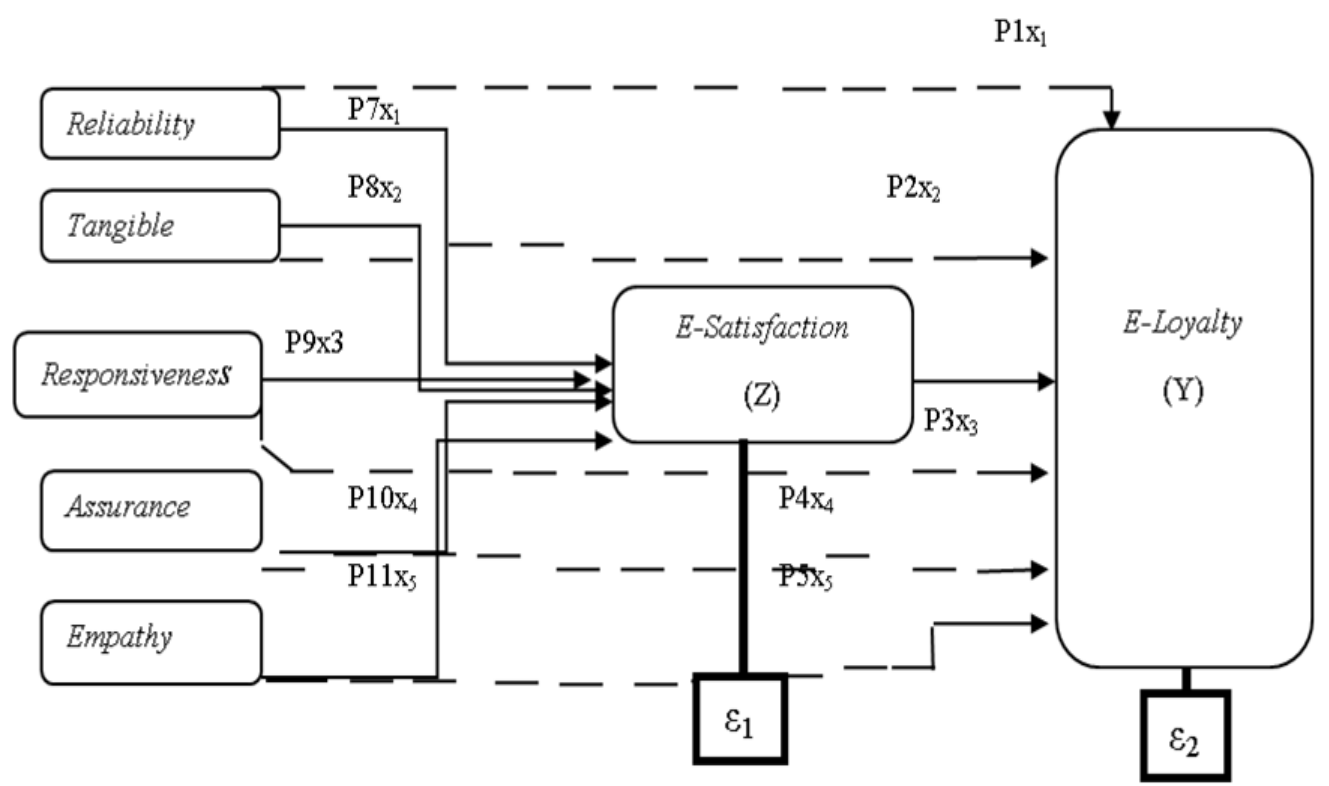

Fig 1. Research Framework

\section{Method}

Quantitative methods are used in this study which aims to test the established hypotheses. The population used is Traveloka service users who are in the Java area. The collection of samples using purposive random sampling with a questionnaire. The sample used was 170 respondents using a questionnaire sent online to collect data. The program used to analyze the data is SPSS 21.0. with the analytical tools used are multiple regression and Path Analysis. The variables in this study include: E-Service Quality (X), E-Loyality (Y), and ESatisfaction (Z).

\section{Result and Discussion}

\subsection{Result}

\subsubsection{Descriptive statistics}

The variables studied in this study are e-service quality including reliability, tangible, responsiveness, assurance and empathy as independent variables and e-loyalty as the dependent variable. Respondents in this study were the majority of men as many as 108 people $(63.5 \%)$ with the majority aged $21-30$ years as many as 125 people $(73.5 \%)$ and the 


\section{$A I C \overline{I E B}$ Annual International Conference \\ on Islamic Economics and Business, 2021}

majority working as civil servants/private/BUMN as many as 73 people $(42,9 \%)$ with the majority earning Rp. 1,000,000 to Rp. 2,500,000,- as many as 91 people (53.5\%), and the majority living in Central Java as many as 54 people (31.8\%).

\subsection{2 $\mathrm{R}^{2}$ Test (Coefficient of Determination)}

Table 4.1 Coefficient of Determination Test Results

\begin{tabular}{lllll}
\hline \multicolumn{4}{c}{ Model Summary } \\
\hline Model & $\mathrm{R}$ & $\mathrm{R}$ Square & Adjusted R Square & Std. Error of the Estimate \\
1 & $.836^{\mathrm{a}}$ & .699 & .688 & 1.3252
\end{tabular}

a. Predictors: (Constant), E-Satisfaction, Tangible, Assurance, Reliability, Empathy, Responsiveness

Source: Processed primary data, 2021

Table 4.1 shows that the Coefficient of Determination (R2) is 0.836 which means it has a strong relationship between the independent variable and the dependent variable because the $\mathrm{R} 2$ value is close to 1 . The adjusted $\mathrm{R} 2$ value is 0.688 which means the contribution of the independent variable that affects the dependent variable is $68.8 \%$, while the remaining $31.2 \%$ is influenced by variables other than in this study.

\subsubsection{F Test}

Table 4.2 F Test Result

\begin{tabular}{lllllll}
\hline Model & & Sum of Squares & df & Mean Square & F & Sig. \\
1 & Regression & 665.971 & 6 & 110.995 & 63.206 & $.000^{\mathrm{b}}$ \\
& Residual & 286.240 & 163 & 1.756 & & \\
& Total & 952.212 & 169 & & &
\end{tabular}

a. Dependent Variable: E-Loyalty

b. Predictors: (Constant), E-Satisfaction, Tangible, Assurance, Reliability, Empathy, Responsiveness

Source: Processed primary data, 2021

Table 4.2 shows that the value of sig. $0.000<0.05$ so it can be concluded that reliability, tangible, responsiveness, assurance, empathy and e-satisfaction affect e-loyalty together. The calculated $\mathrm{F}$ value is $63.206>\mathrm{F}$ table (2.15).

\subsubsection{T Test}

Table 4.3 T Test Result

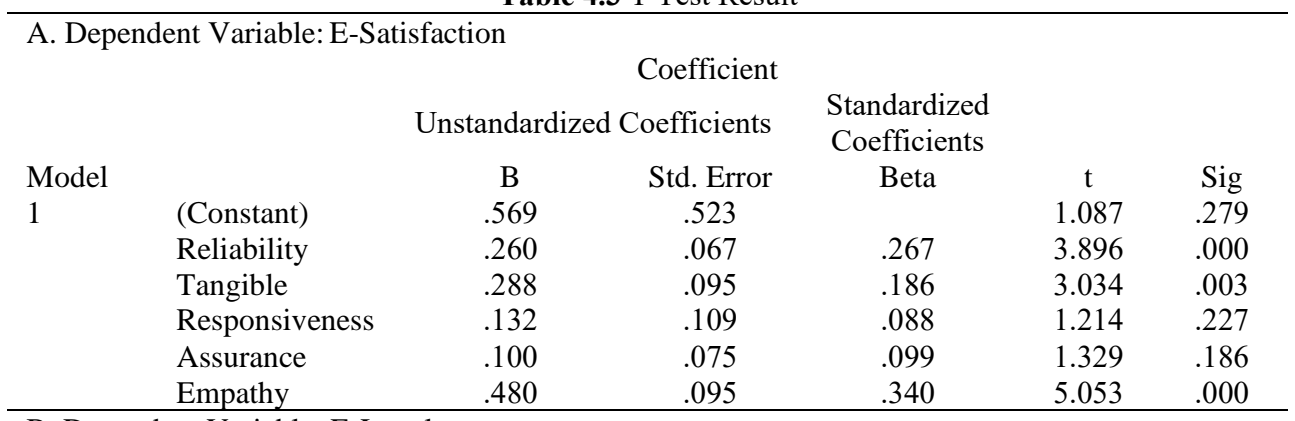

B. Dependent Variable: E-Loyalty

Coefficient 


\section{$A \bar{C} \quad$ Annual International Conference \\ on Islamic Economics and Business, 2021}

\begin{tabular}{|c|c|c|c|c|c|c|}
\hline \multirow{9}{*}{$\begin{array}{l}\text { Model } \\
1\end{array}$} & & \multicolumn{2}{|c|}{ Unstandardized Coefficients } & \multirow{3}{*}{$\begin{array}{c}\text { Standardized } \\
\text { Coefficients } \\
\text { Beta }\end{array}$} & \multirow{3}{*}{$\begin{array}{c}\mathrm{t} \\
.656\end{array}$} & \multirow{3}{*}{$\begin{array}{l}\mathrm{Sig} \\
.513\end{array}$} \\
\hline & & B & Std. Error & & & \\
\hline & (Constant) & .419 & .639 & & & \\
\hline & Reliability & .191 & .085 & .179 & 2.246 & .026 \\
\hline & Tangible & -.043 & .119 & -.026 & -.365 & .715 \\
\hline & Responsiveness & .049 & .133 & .030 & .371 & .711 \\
\hline & Assurance & -.096 & .092 & -.087 & -1.045 & .297 \\
\hline & Empathy & .206 & .124 & .134 & 1.661 & .099 \\
\hline & E-Satisfaction & .701 & .095 & .642 & 7.384 & .000 \\
\hline
\end{tabular}

Source: Processed primary data, 2021

Table 4.3 on the dependent variable e-satisfaction shows that realibility, tangible, and empathy have a positive and significant effect on e-satisfaction, while responsiveness and assurance have a negative and insignificant effect on e-satisfaction. In the dependent variable, e-loyalty shows that reliability and e-satisfaction have a positive and significant effect on eloyalty, while tangible, responsiveness, assurance, and empathy have a negative and insignificant effect on e-loyalty. Therefore, Traveloka should improve e-service quality in terms of reliability, tangible, and empathy to increase e-satisfaction, because e- satisfaction positively and significantly increases customer e-loyalty to Traveloka.

\subsubsection{Path Analyze Test}

Model $1(\mathrm{Y}=\beta \mathrm{o}+\beta 1 \mathrm{rel}+\beta 2 \operatorname{tang}+\beta 3$ resp $+\beta 4 \mathrm{ass}+\beta 5 \mathrm{emp}+\mathrm{e} 1)$

Table 4.4 Equation Test Results 1

\begin{tabular}{lcccc}
\hline \multicolumn{5}{c}{ Model Summary } \\
\hline Model & $\mathrm{R}$ & R Square & $\begin{array}{c}\text { Adjusted R } \\
\text { Square }\end{array}$ & Std. Error of the Estimate \\
\hline 1 & .774 & .599 & .587 & 1.5262
\end{tabular}

a. Predictors: (Constant), Empathy, Tangible, Responsiveness, Reliability, Assurance

Source: Processed primary data, 2021

Model $2\left(\mathrm{Y}=\beta \mathrm{o}+\beta 1\right.$ rel $+\beta 2 \operatorname{tang}+\beta 3$ resp $+\beta 4$ ass $+\beta 5$ emp $+\beta 6$ esat $\left.+\mathrm{e}_{1}\right)$

Table 4.5 Equation Test 2

\begin{tabular}{lcccc}
\hline \multicolumn{4}{c}{ Model Summary } \\
\hline Model & $\mathrm{R}$ & $\mathrm{R}$ Square & $\begin{array}{c}\text { Adjusted R } \\
\text { Square }\end{array}$ & Std. Error of the Estimate \\
\hline 1 & .836 & .699 & .688 & 1.3252
\end{tabular}

a. Predictors: (Constant), E-Satisfaction, Tangible, Assurance, Reliability, Empathy,

Responsiveness

Source: Processed primary data, 2021

\subsection{Discussion}

\subsubsection{Reliability, Tangible, Responsiveness, Assurance, Empathy and E- Satisfaction}

The reliability variable has a positive and significant effect on e-satisfaction. In line with Laurent (2016) which shows that muslim travellers are satisfied with Traveloka's performance in responding to complaints and problems they face. In line with Metayunika 


\section{$A \mathrm{IC} \quad$ Annual International Conference \\ on Islamic Economics and Business, 2021}

(2013) Tangible variables have a positive and significant effect on e-satisfaction, indicating that muslim travellers are satisfied with the physical appearance of the Traveloka interface. The responsiveness variable has a positive and significant effect on e-satisfaction. This is in line with Marlius (2017) which shows that muslim travellers are satisfied with the servicesand security guarantees provided by Traveloka, while the assurance variable has a negative and insignificant effect on e-satisfaction which indicates that service guarantees do not affect customer satisfaction because online transactions have become a lifestyle and are contrary to Marlius (2017). In line with Kholifah (2020) that the empathy variable has a positive and significant effect on e-satisfaction which shows that muslim travellers are satisfied with the attention and recommendations for halal tourist attractions provided by Traveloka.

\subsubsection{E-Satisfaction and E-Loyalty}

The e-satisfaction variable has a positive and significant effect on e-loyalty. This is in line with Riza \& Sutopo (2017), Magdalena \& Jaolis (2018), Ashoer et al. (2019), Budiman et al. (2020) which shows that Muslim tourists become loyal muslim travellers of Traveloka because they are satisfied with the services provided.

\subsubsection{Reliability, Tangible, Responsiveness, Assurance, Empathy, Reliability and E- Loyalty}

The reliability variable has a positive and significant effect on e-loyalty. This shows that reliable service causes loyal muslim travellers to use Traveloka. Tangible variables have a negative and insignificant effect on e-loyalty. This shows that the physical appearance of the Traveloka interface does not affect customer loyalty. The responsiveness variable has a negative and insignificant effect on e-loyalty. This shows that the responsiveness of the company does not affect the loyalty of Traveloka muslim travellers. Assurance variable has a negative and insignificant effect on e-loyalty. This shows that Traveloka's reliable service does not affect customer loyalty. Empathy variable has a negative and insignificant effect on e-loyalty. This shows that Traveloka's attention and recommendations for halal places do not affect the loyalty of Muslim travellers.

\subsubsection{E-Loyalty, Tangible, Responsiveness, Assurance, Empathy, and E- Satisfaction}

E-satisfaction can mediate the effect of reliability on e-loyalty because Traveloka's reliability can make muslim travellers feel satisfied and loyal using Traveloka. E- satisfaction can mediate the effect of reliability on e-loyalty, because the good physical appearance of the Traveloka interface (tangible) causes muslim travellers to be satisfied and loyal to using Traveloka. E-satisfaction cannot mediate the effect of responsiveness on e- loyalty, because only the responsiveness aspect provided by Traveloka cannot make muslim travellers feel satisfied and if muslim travellers are not satisfied, muslim travellers tend to be disloyal to Traveloka. E-satisfaction cannot mediate the effect of assurance on e- loyalty, because the presence or absence of a guarantee from the Traveloka application does not make muslim travellers satisfied, so muslim travellers tend to be disloyal to Traveloka. E-satisfaction can mediate the effect of empathy on e-loyalty, because the attention and recommendations given by Traveloka causes muslim travellers to be satisfied and loyal to Traveloka. 


\section{$A I C \bar{C} \quad$ Annual International Conference \\ on Islamic Economics and Business, 2021}

\section{Conclusion}

Based on the results of data analysis and discussion, it can be concluded that: e-service quality aspects of reliability, tangible, and empathy have a positive and significant effect on esatisfaction while responsiveness and assurance aspects do not affect e-satisfaction. Esatisfaction has a positive and significant effect on e-loyalty. E-service quality aspects of reliability have a positive and significant effect on e-loyalty while aspects of tangible, responsiveness, assurance, empathy do not affect e-loyalty. E-satisfaction can mediate the effect of reliability, tangible, and empathy on e-loyalty, while responsiveness and assurance have no mediating effect on e-satisfaction on e-loyalty.

The results of this study can strengthen the existing theory that e-satisfaction can mediate the effect of reliability, tangible, and empathy on e-loyalty, while responsiveness and assurance have no mediating effect of e-satisfaction on e-loyalty. While the practical implications in this study are used as input for platform providers in order to improve the quality of services provided by platform providers to Muslim travellers.

\section{References}

Ashoer, M., Prihatin, E., \& Ratnasari, R. (2019). Pengaruh E-Service Quality Terhadap ESatisfaction Pada Pelanggan Situs Toko Online Brodo. Jurnal Bisnis, Manajemen, Dan Informatika, 238-251.

Asih, R. R. D., \& Pratomo, L. A. (2018). Peran Mediasi E-Satisfaction Dan E-Trust Terhadap E-Loyalty. Jurnal Manajemen Dan Pemasaran Jasa, 11(1), 125-144. https://doi.org/10.25105/jmpj.v11i1.2537

Boohene, R., \& Agyapong, G. K. Q. (2011). Analysis of the Antecedents of Customer Loyalty of Telecommunication Industry in Ghana: The Case of Vodafone (Ghana). International Business Research, 4(1), 229-240. https://doi.org/10.5539/ibr.v4n1p229

Budiman, A., Yulianto, E., \& Saifi, M. (2020). Pengaruh E-Service Quality Terhadap ESatisfaction Dan E- Loyalty Nasabah Pengguna Mandiri Online. Profit, 14(1), 1-11. https://doi.org/10.21776/ub.profit.2020.014.01.1

Fitriani, A. (2018). Pengaruh E-Trust dan E-Service Quality terhadap E-Loyalty dengan ESatisfaction sebagai Variabel Intervening (Studi pada Pengguna E-Commerce C2C Shopee). UIN Alauddin Makassar.

Gotama, F., \& Indarwati, T. A. (2019). The Effects of E-Trust and E-Service Quality to ELoyalty with E-Satisfaction as the Mediation Variable (The Study of Bebas Bayar Application User's in Indonesian). Jurnal Minds: Manajemen Ide Dan Inspirasi, 6(2), 145-158. https://doi.org/10.24252/minds.v6i2.9503

Haria, T. T., \& Mulyandi, M. R. (2019). Pengaruh E-Service Quality terhadap E-Satisfaction pada Pengguna Aplikasi Mobile. Prosiding Seminar Dan Lokakarya Kualitatif Indonesia 2019, 135-140.

Hendika, Idrus, M. S., Surachman, \& Suman, A. (2011). Pengaruh E-service Quality dan Net Oriented Lifestyle terhadap E-satisfaction dan E-loyalty (Studi pada Pelanggan Eticketing di Kota Balikpapan). Jurnal Aplikasi Manajemen, 9(1), 85-93.

Hidayah, R. T., \& Utami, E. M. (2017). E-Service Quality and E-Recovery Service Quality on E-Satisfaction Lazada.Com. Jurnal Riset Manajemen Sains Indonesia, 8(2), 257274. https://doi.org/10.21009/jrmsi.008.2.05

Irwansyah, A., \& Mappadeceng, R. (2018). Pengaruh E-Service Quality Terhadap Customer Loyalty Melalui Customer Satisfaction Pada Toko On Line Buka Lapak. J-MAS (Jurnal Manajemen Dan Sains), 3(2), 128-136. https://doi.org/10.33087/jmas.v3i2.50

Kholifah, U. N. (2020). Pengaruh Kualitas Produk dan Kualitas Layanan Terhadap Loyalitas dengan Kepuasan Nasabah Sebagai Variabel Intervening (Studi Pada Bank 


\section{$A \mathrm{IC} \quad$ Annual International Conference \\ on Islamic Economics and Business, 2021}

BRISyariah Kantor Cabang Pembantu Magelang). IAIN Salatiga.

Komara, A. T. (2013). Pengaruh E-Service Quality Dan E-Recovery Service Quality Terhadap E-Satisifaction Serta Implikasinya Pada E-Loyalty Pelanggan Maskapai Penerbangan Air Asia. Jurnal Ekonomi, Bisnis \& Entrepreneurship, 7(2), 105-115.

Laurent, F. (2016). Pengaruh E-Service Quality Terhadap Loyalitas Pelanggan Go-Jek Melalui Kepuasan Pelanggan. Agora, 4(2), 95-100.

Magdalena, A., \& Jaolis, F. (2018). Analisis Antara E-Service Quality, E-Satisfaction, dan E-Loyalty Dalam Konteks E-Commerce Blibli. Jurnal Strategi Pemasaran, 5(2), 111.

Marlius, D. (2017). Keputusan pembelian berdasarkan faktor psikologis dan bauran pemasaran pada PT. Intercom Mobilindo Padang. Jurnal Pundi, 1(1), 57-66.

Melinda. (2017). Pengaruh E-Service Quality Terhadap E-Loyalty Pelanggan Go-Jek Melalui E-Satisfaction Pada Kategori Go-Ride. Agora, 5(1), 1-6.

Metayunika, V. (2013). Analisis Pengaruh Kualitas Pelayanan (Tangible, Reliability, Responsiveness, Assurance, dan Emphaty) Terhadap Kepuasan Konsumen (Studi Pada Dealer Mitsubishi PT Bumen Redja Abadi Semarang). Universitas Diponegoro.

Nasution, H., Fauzi, A., \& Rini, E. S. (2019). The effect of e-service quality on e-loyalty through e-satisfaction on students of Ovo application users at the Faculty of Economics and Business, University of North Sumatra, Indonesia. European Journal of Management and Marketing Studies, 4(1), 146-162. https://doi.org/10.5281/zenodo.3360880

Prasmara, A. E., Rachma, N., \& Primanto, A. B. (2020). Pengaruh Online Marketing Dan EService Quality Terhadap E-Loyalty Dengan ESatisfaction Sebagai Variabel Intervening Pada Online Shop Khayrscraf. E - Jurnal Riset Manajemen, 9(8), 29-44.

Pudjarti, S., Nurchayati, N., \& Putranti, H. R. D. (2019). Penguatan Kepuasan Model Hubungan E-Service Quality Dan E-Loyalty Pada Konsumen Go-Jek Dan Grab. Sosiohumaniora: Jurnal Ilmu-Ilmu Sosial Dan Humaniora, 21(3), 237-246. https://doi.org/10.24198/sosiohumaniora.v21i3.21491

Riza, S., \& Sutopo. (2017). Analisis Pengaruh E-Service Quality , Kualitas Informasi dan Persepsi Kemudahan Terhadap E-Loyalty dengan E-Satisfaction sebagai Variabel Intervening. Diponegoro Journal Of Management, 6(4), 1-13.

Sativa, A. (2016). Analisis Pengaruh E-Trust dan E-Service Quality terhadap E-Loyalty dengan E-Satisfaction sebagai Variabel Intervening (Studi pada Pengguna ECommerce C2C Tokopedia). Universitas Diponegoro.

Suprapti, S., \& Suparmi. (2020). Membangun e-Loyality dan e-Satisfaction melalui e-Service Quality Pengguna Goride Kota Semarang. JKBM (Jurnal Konsep Bisnis Dan Manajemen), 6(2), 240-255. https://doi.org/10.31289/jkbm.v6i2.3795

Syafiq, A., \& Haryono. (2010). Analisis Pengaruh Kualitas Layanan, Kepercayaan dan Kepuasan Terhadap Loyalitas Pelanggan Telkomspeedy dengan Metode Structural Equation Modeling. 1-8.

Tobagus, A. (2018). Pengaruh E-Service Quality terhadap E-Satisfaction pada Pengguna di Situs Tokopedia. Agora, 6(1), 1-10.

Udo, G. J., Bagchi, K. K., \& Kirs, P. J. (2010). An assessment of customers' e-service quality perception, satisfaction and intention. International Journal of Information Management, 30(6), 481-492. https://doi.org/10.1016/j.ijinfomgt.2010.03.005

Wulandari, D. (2017). Pengaruh E-Service Quality Terhadap E-Loyalty Dengan ESatisfaction Sebagai Variabel Mediasi Dan E-Trust Sebagai Variabel Moderasi (Studi Empiris Pada Top 3 Toko Online C2C). Journal Of Chemical Information And Modeling, 53(9), 1689-1699. 